\title{
Application of Regionalism Method Based Cropped Ecology for Determination Production Vacuity of Irrigated Wheat Yield in Arid and Semi-Arid Regions, Iran
}

\author{
Mehdi Mardian*
}

\begin{abstract}
In this study, with goal the estimation of yield production potential in 30 provinces center in Iran, firstly using factor and cluster analysis and with nine climate factors, the stations were classified. According to the percentage of variance and special values of effective factors, KMO value was equal to 0.598 that four climatic parameters including mean temperature, relative humidity, wind speed and precipitation were selected in grouping process. As a result, regionalism method based cropped ecology in arid low precipitation regions of the country could not estimate potential production of wheat yield. In region with semi-arid- semi humid climate, the lowest and highest yield vacuity percent with 30.9 and 53.5 is in the Ardebil and Ilam stations, respectively. Also results showed that model from between the climatic factors, has the greatest sensitivity to average temperature. This has caused that the lowest yield vacuum be in regions with low precipitation and dry climates with 15 and 27.5 percent, respectively. Conciliation of results represented that regionalism method based cropped ecology is one of the appropriate method for predicting wheat production and determining production vacuity in different climatic regions
\end{abstract}

Keywords-Factor and cluster analysis, Climate changes, Meteorological data, Wheat production efficiency.

\section{INTRODUCTION}

$\mathrm{D}^{\mathrm{sin}}$ ue to the limitations in agricultural section to wheat production increasing through the production factors development of and changes in existing technology, applying a predictive model on based different climate factors could be useful. Regionalism method based cropped ecology is a suitable models. It is assumed that the climatic requirements is suitable and water, nutrients, salinity, pests and diseases haven't effect on crop growth and yield potential [4].

In recent years wheat production potential in worldwide has increased substantially. Many studies have been conducted to analyze such increases [2]. Some of these studies have focused on production on based climate factors. So the most important climatic factors affecting on crop production potential include precipitation, temperature, radiation, and growing season [3].

Mehdi Mardian is with Young Researchers and Elite Club, Arak Branch, Islamic Azad University, Arak, Iran (corresponding author's phone: +989184872832; e-mail: mehdimardian@gmail.com).
So an increase $100 \%$ of $\mathrm{CO}_{2}$ and $4 \mathrm{C}^{\circ}$ of temperature lead to 30 to 40 percent increases in yield [5]; Increase in temperature can reduced production potential in rice and wheat [6]; an increase in yield due to climatic conditions (temperature and precipitation) is showed [7]; In regions with high latitudes including developed countries, temperature increase in due to the longer growing season [8], [9]; production vacuity in years with high production is more than years with low production [10].

Wheat is a strategic crop throughout the world [1] including Iran that has a suitable, but diverse, ecology for wheat production. Therefore, Iran has advantages for the development of productive high-quality varieties of wheat, a nationally strategic crop. The aim of this study is an evaluation from production potential of irrigated wheat by regionalism method based cropped ecology in arid and semi-arid regions, Iran. So this study can be a program to clarify the management of agricultural production in the country.

\section{MATERIAL AND METHODS}

In this study, with goal the estimation of yield production potential in 30 provinces center in Iran, firstly using factor and cluster analysis and with nine climate factors, the stations were classified. Climate data was collected for a period 30 years (1980 to 2010) from synoptic stations of provinces centers. Factor and cluster analysis was carried using SPSS 20 software. Therefore was determined regions with similar climate including arid and semi-arid.

Average values of actual production for winter wheat in each center of groups were collected from data and information technology site of Ministry of Agriculture - Jahad. Then was determined the production potential and production vacuity ( $\mathrm{kg}$ per hectare) using the regionalism method based cropped ecology. So, the estimated values of parameters in regionalism method based cropped ecology and actual and potential of wheat yield was determined in two regional groups. Also percentage of production vacuity between actual and potential yield from lack climatic requirements for each group was determined. 


\section{RESULTS}

According to results of variance percentage and special values of effective factors, KMO value was equal to 0.598 that four climatic parameters including mean temperature, relative humidity, wind speed and precipitation were selected in grouping process (table I).

TABLE I. VARIANCE PERCENTAGE AND SPECIAL VALUES OF EFFECTIVE

\begin{tabular}{lccc}
\multicolumn{4}{c}{ FACTORS } \\
\hline \hline Factor & Variance\% & Cumulative\% & $\begin{array}{c}\text { Total } \\
\text { eigenvalue }\end{array}$ \\
\hline Average Temperature & 39.80 & 39.80 & 3.58 \\
Relative Humidity & 30.65 & 75.45 & 2.76 \\
Wind Speed & 14.49 & 84.95 & 1.30 \\
Average precipitation & 12.20 & 97.15 & 1.01 \\
KMO & & & 0.598 \\
\hline \hline
\end{tabular}

Table II indicated the difference between actual and potential production vacuity on based climatic requirements.

TABLE II. DIFFERENCE BETWEEN ACTUAL AND POTENTIAL PRODUCTION VACUITY

\begin{tabular}{lccc}
\hline \hline Arid & $\begin{array}{c}\text { Production } \\
\text { Vacuity } \%\end{array}$ & Semi-Arid & $\begin{array}{c}\text { Production } \\
\text { Vacuity \% }\end{array}$ \\
\hline Mashhad & -37.4 & Birjand & -47.6 \\
Qazvin & -36.7 & Kerman & -12.9 \\
Bojnoord & -43.7 & Yazd & - \\
Sanandaj & -51.7 & Zahedan & -52.1 \\
Kermanshah & -39.6 & Qom & - \\
Tabriz & -52.2 & Esfahan & -14.6 \\
Arak & -44.8 & Shiraz & - \\
Shahrekord & -34.6 & Tehran & - \\
Zanjan & -45.8 & Semnan & -10.2 \\
Hamedan & -40.7 & mean & -27.5 \\
Orumieh & -47.9 & & \\
Ilam & -53.5 & & \\
Khorram abad & -46.7 & & \\
Yasooj & -41.7 & & \\
Ardebil & -30.9 & & \\
mean & -43.2 & & \\
\hline \hline
\end{tabular}

\section{DISCUSSION}

According to results, separated nine provinces center in arid region including: Birjand, Kerman, Yazd, Zahedan, Qom, Isfahan, Shiraz, Tehran and Semnan. In semi-arid- semi humid climate there is 15 provinces center including: Mashhad, Qazvin, Bojnoord, Sanandaj, Kermanshah, Tabriz, Arak, Shahrekord, Zanjan, Hamedan, Orumieh, Ilam, Khorramabad, Yasooj and Ardebil. Then, the estimated values of parameters in regionalism method based cropped ecology and actual and potential of wheat yield was determined in two regional groups. Also percentage of production vacuity between actual and potential yield from lack climatic requirements for each group was determined.

As a result of regionalism method based cropped ecology, in semi-arid- semi humid climate, the lowest and highest yield vacuity percent with 30.9 and 53.5 is in the Ardebil and Ilam stations, respectively. Also the average percentage of yield vacuity in this group is 43.2 percent. In regions with arid climate, the minimum and maximum of yield vacuity percentage is in the Semnan and Zahedan stations with 10.2 and 52.1 percent, respectively. Also the average percentage of yield vacuity in this group is 27.5 percent.

\section{CONCLUSION}

As conclusion, model from between the climatic factors, has the greatest sensitivity to average temperature. This has caused that the lowest production vacuum be in arid regions with 27.5 percent. Conciliation of results represented that regionalism method based cropped ecology is one of the appropriate methods for predicting wheat production and determining production vacuity in different climatic regions.

\section{REFERENCES}

[1] C. T. De-Wit, "Photosynthesis: Its relationship to overpopulation," in IMC Symposium. Harvesting the Sun: Photosynthesis in plant life. Chicago, 1967, pp. 315-320.

[2] H. Pei, L. Min, Y. Qi, X. Liu, Y. Jia, Y. Shen, C. Liu, "Impacts of varied irrigation on field water budegts and crop yields in the North China Plain: Rainfed vs. irrigated double cropping system," Agricultural Water Management, 2017, vol. 190, pp. 42-54.

[3] M. Parry, C. Rosenzweig, A. Inglesias, M. Livermore, G. Gischer, "Effects of climate change on global food production under SRES emissions and socio-economic scenarios," Glob. Environ. 2004, vol. 14, pp. 53-67.

[4] H.S. Mavi, R. Mathauda, G.S. Singh, O.P. Mahi, "Climate change and wheat yield in the Punjab (India)," Proc. Symp. On Climate Change, Natural Disasters and Agricultural Strategies. Beijing, 1993, pp. 5865.

[5] M. Lal, K.K. Singh, L. Rathore, G. Srinivasan, S.A. Saseendran, "Vulnerability of rice and wheat yields in NW India to future changes in climate," Agric. Forest Meterol.1998, vol. 89, pp. 101-114.

[6] D. Lobell, "Analysis of wheat yield and climatic trend in Mexico," Field Crops Research J.2005, vol. 94, pp. 250-256.

[7] J. Wolf, "Comparison of two potato simulation models under climate change," Climate Research J.2002, vol. 21, pp.173-186.

[8] P.K. Aggarval, N. Karla, S.K. Bandyopadhyay, S. Selvarjan, "A systems approach to analyze production options for wheat in India," Ecoregional Approaches for Sustainable land Use and Food Production. Springer Netherlands, 1995, vol. 4, pp. 167-186.

[9] L.G. Abeledo, R. Savin, G.A. Slafer, "Wheat productivity in the Mediterranean Ebro Valley: Analyzing the gap between attainable and potential yield with a simulation model," European Journal of Agronomy, 2008, vol. 28, pp. 541-550.

[10] N. Gummadova, M. Keserb, B. Akina, M. Cakmakc, Z. Mertd, S. Tanere, I. Ozturkf, A. Topalg, S. Yazard, A. Morgounova, "Genetic gains in wheat in Turkey: Winter wheat for irrigated conditions," The Crop Journal, 2015, vol. 3, pp. 507-516. 